\title{
PENGARUH PEMANFAATAN LINGKUNGAN SEKOLAH TERHADAP PENINGKATAN KEMAMPUAN SISWA DALAM MENULIS PUISI
}

\author{
Emilda \\ emilda.az@gmail.com
}

Universitas Malikussaleh

\begin{abstract}
Abstrak
Pembelajaran merupakan proses interaksi antara peserta didik dengan lingkungannya sehingga terjadi perubahan tingkah laku ke arah yang lebih baik. Dalam pembelajaran, tugas guru yang utama adalah mengkondisikan lingkungan agar terjadinya perubahan perilaku bagi peserta didik. Penelitian ini bertujuan untuk mengetahui kemampuan siswa dalam menulis/menciptakan puisi dan mengetahui berapa besar pengaruh lingkungan sekolah terhadap puisi yang ditulis siswa. Penelitian ini juga diarahkan untuk menyajikan/ memberikan langkahlangkah dalam mengajar sastra khususnya puisi. Metode penelitian yang digunakan yakni metode tindakan kelas dengan teknik pengumpulan data melalui siklus yang dilakukan dengan tahapan perencanaan, tindakan pengamatan dan refleksi. Hasil penelitian menunjukkan bahwa dalam menulis puisi dengan memanfaatkan lingkungan sekolah sangat berpengaruh terhadap peningkatan nilai menulis puisi yang dibuat siswa. Dari hasil penulisan puisi siswa didapati hasil bahwa struktur fisik tes awal 41,65, tes siklus pertama 43,9 , siklus kedua 44,15 dan struktur batin tes awal 27,60, tes siklus pertama 28,33 dan tes siklus kedua 29,35. Nilai rata-rata (Mean) kemampuan siswa memanfaatkan lingkungan dalam menulis puisi menunjukkan peningkatan dari tes awal sebesar 69,23, tes siklus pertama 72,17 dan tes siklus kedua menjadi 73,50
\end{abstract}

Kata kunci: bahasa indonesia, pembelajaran, puisi, tes siklus, tindakan kelas.

\begin{abstract}
Learning is a process of interaction between students and their environment so that changes in behavior occur for the better. In learning, the main task of the teacher is to condition the environment so that behavior change occurs for students. This study aims to determine the ability of students to write / create poetry and find out how much influence the school environment has on students written poetry. This research is also directed to present / provide steps in teaching literature, especially poetry. The research method used is the classroom action method with data collection techniques through cycles conducted with the stages of planning, observation and reflection. The results showed that in writing poetry by utilizing the school environment is very influential on increasing the value of writing poetry made by students. From the results of writing poetry students found that the physical structure of the initial test 41.65 , the first cycle test 43.9, the second cycle 44.15 and the inner structure of the initial test 27.60, the first cycle test 28.33 and the second cycle test 29.35 . The average value (Mean) of the ability of students to use the environment in writing poetry shows an increase from the initial test of 69.23, 72.17 first cycle test and second cycle test to 73.50
\end{abstract}

Keywords: class action, cycle test, learning, indonesian, poetry.

\section{PENDAHULUAN}

Pembelajaran pada hakikatnya adalah proses interaksi antara peserta didik dengan lingkungannya sehingga terjadi perubahan tingkah laku ke arah yang lebih baik. Dalam pembelajaran, tugas guru yang utama adalah mengkondisikan lingkungan agar terjadinya perubahan perilaku bagi peserta didik. Umumnya pelaksanaan pembelajaran mencakup tiga hal yang sangat penting dan bermanfaat yaitu pretest, proses dan postest.

Pembelajaran merupakan suatu situasi yang melibatkan dua perbuatan yitu perbuatan oleh siswa dan perbuatan mengajar oleh guru. Dalam proses pengajaran terdapat beberapa unsur yang dapat mempengaruhi, yakni tujuan pengajaran, bahan pelajaran, metode dan alat raga, serta penilaian/evaluasi (Nasution, 1986: 11).

Hakikat pengajaran sastra khususnya pengajaran puisi adalah memperkenalkan siswa-siswi nilai-nilai yang dikandung dalam karya sastra dan mengajak siswa ikut menghayati pengalaman-pengalaman yang disajikan dalam karya sastra. Secara lebih khusus pengajaran sastra bertujuan mengembangkan kepekaan siswa terhadap nilai-nilai indrawi, nilai akali, nilai efektif, nilai keagamaan, dan nilai sosial, secara sendiri sendiri atau gabungan dari keseluruhan itu sebagaimana yang tercermin dalam karya sastra, (Bambang, 1999: 59-61).

Rahmanto (1996) mengatakan, bahwa apabila hendak memilih bahan 
pengajaran sastra dengan tepat, beberapa, aspek perlu dipertimbangkan. Pertama aspek bahasa, kedua aspek kematangan jiwa (psikologi) dan aspek latar belakang kebudayaan siswa.

Berdasarkan pendapat di atas guru dituntun untuk dapat melaksanakan pengajaran dan dapat menentukan bentuk interaksi yang tepat sesuai materi yang diajarkan. Sebagai sesuatu kegiatan yang terencana, kegiatan belajar mangajar (KBM) tentu mempunyai tujuan yang hendak dicapai. Untuk mencapai tujuan pengajaran tersebut diperlukan metode mengajar yang baik.

Metode adalah yang dalam fungsinya merupakan alat pencapaian tujuan. Hal ini berlaku untuk guru maupun siswa. Semakin baik metode yang digunakan makin efektif pencapaian tujuan. Dengan demikian dapat disimpulkan bahwa keberhasilan pengajaran salah satunya ditentukan melalui metode mengajar yang sesuai dengan lingkungan mengajar dan materi yang disampaikan. Perencanaan pelajaran telah menghasilkan bermacam-macam model pembelajaran. Model pembelajaran adalah berupa bagan-bagan secara grafis dapat menggambarkan dengan mudah rututan kegiatan yang harus dilalui oleh setiap pengembang (pengajar). Perencanaan pengajaran tampil sedemikian rupa sehingga dapat dilihat secara simultan. Artinya terlihat serentak, sakaligus dengan lengkap semua proses pembelajaran dari awal sampai akhir. Suatu model sebenarnya bukan tergantung pada polanya, atau pada jumlah tahap atau langkah yang harus ditempuh dan tidak pula tergantung pada rambu-rambu/ alur pemikiran yang digunakan. Model mana yang harus dipilih, tergantung pada beberapa pertimbangan, yakni tingkat masalah yang dihadapi, tujuan yang hendak dicapai, lembaga yang akan menerapkan model itu, dan terhadap subjek mana metode ini diterapkan.

Selanjutnya, perancangan model pengajaran setidak-tidaknya ada empat komponen pembelajaran, yakni tujuan mana yang harus dicapai, pengalaman belajar apa yang diberikan kepada siswa (materi), bagaimana mengorganisasikan pengalaman belajar tersebut (strategis), dan begaimana mengetahui tercapai tidaknya tujuan yang diharapkan (evaluasi). Pengajaran sastra juga mengacu pada model yang dilaksanakan pada pengajaran. Selama ini pengajaran sastra hanya bersifat tempelan saja pada pengajaran bahasa. Dalam rangka mencapai tujuan pengajaran sastra yang maksimal, guru harus melaksanakan pengajaran sastra secara independen tanpa menggabungkan dengan pelajaran bahasa. Pengajaran sastra khususnya pengajaran puisi di sekolah-sekolah masih sangat jarang dilakukan oleh guru. Hal ini diakibatkan kurangnya pengetahuan guruguru tentang sastra serta guru merasa kewalahan dalam menentukan metode yang tepat dalam mengajarkan sastra kepada peserta didik di sekolah.

Sebelumnya sudah pernah dilakukan beberapa penelitian tentang metodemetode untuk meningkatkan minat siswasiswi dalam menulis puisi seperti penelitian yang dilakukan oleh Nida Rahmawati dengan judul peningkatan kemampuan menulis puisi bebas melalui penggunaan metode estafet writing (Penelitian Tindakan Kelas pada Siswa Kelas VIII F SMP Negeri 1 Baregbeg).

Berdasarkan uraian di atas penting diadakan sutau penelitian sastra khususnya pengajaran puisi di sekolah dengan menggunakan metode yang dapat meningkatkan kemampuan dalam kemauan siswa mempelajari dan mengaplikasikan teori sastra yang telah dipelajari dalam proses belajar mengajar. Tujuan dari penelitian ini untuk mengetahui kemampuan siswa dalam menulis/ menciptakan puisi dan mengetahui berapa besar pengaruh lingkungan sekolah terhadap puisi yang ditulis siswa. Penelitian ini juga diarahkan untuk menyajikan/ memberikan langkahlangkah dalam mengajar sastra khususnya 
puisi. Penelitian ini dapat memberikan kontribusi dan manfaat kepada siswa, guru, dan lembaga pendidikan terkait. Kontribusi yang dimaksud sebagai berikut:

1) Bermanfaat untuk membangkitkan minat siswa dalam menulis puisi dengan pemanfaatan lingkungan sekolah.

2) Memberikan teknik, cara atau metode baru dalam mengajar khususnya menulis puisi.

3) Penelitian ini diharapkan dapat menjadi acuan dalam menyusun kurikulum.

\section{KAJIAN TEORI}

Prosa adalah karangan bebas yang tidak terkait oleh bentuk, irama dan rima. Oleh karena itu, pembaca dapat dengan mudah menangkap pesan yang ada dalam karya prosa tersebut. Prosa secara garis besar dapat dibedakan dua bagian, prosa lama dan prosa baru. Proses perbedaannya ini didasarkan pada urutan waktu penciptaannya atau proses kelahirannya. Selain dari itu, nilai-nilai yang dikandung juga menjadi hal yang signifikan dalam pembagian prosa. Prosa lama terdiri atas hikayat, tambo (silsilah), dongeng, fabel, lagenda, sage, mite, parable, dogeng orang pander, dan epos. Semua jenis prosa ini merupakan hasil cipta seseorang yang diciptakan pada masa dahulu. Jenis prosa lama ini sangat dikenal di masyarakat luas karena pengaruhnya terhadap kehidupan masyarakat. Seperti hikayat, banyak masyarakat mempopulerkan sesuatu hal dengan menggunakan sarana prosa lama, yakni hikayat.

Prosa baru terdiri atas cerpen, novel, roman, fregmen, biografi, otobiografi, esai, kritik sastra dan riwayat perjalanan. Jenis prosa baru ini sekarang banyak dipergunakan dalam kehidupan sehari-hari. Selain dalam kehidupan bermasyarakat, jenis prosa ini juga dipergerakan di lingkungan sekolah, baik sekolah kejuruan maupun non kejuruan.
Dalam hal cita mencipta prosa, ada dua hal yang patut mendapat perhatian, yakni pembelajaran dan berlatih. Pembelajaran, dapat dilakukan dengan mencontoh (bukan menyontek), membaca karya teman lain baik yang terkenal maupun yang belum, bertanya kepada teman lain, bersedia dikritik dan seterusnya. Pengajar utama seorang sastrawan adalah "membaca", baik membaca yang gigih dan diteruskan mau berlatih, tentu tak ada dalam proses kreativitas dalam menghasilkan karya yang maksimal (Endraswara, 2003: 212).

Ada hal yang penting diperhatikan dalam menulis atau menciptakan prosa, yakni unsur-unsur yang membangun prosa. Unsur intrinsik dan unsur ekstrinsik, kedua unsur tersebut saling berkaitan.

Unsur intrinsik, plot atau alur, tokoh dan penokohan, latar atau setting, sudut pandang atau titik kisah, gaya, dan tema. Unsur ekstrinsik yakni latar belakang pendidikan pengarang, ideologi yang dianut oleh pengarang, agama yang dianut oleh pengarang, kedudukan pengarang dalam masyarakat, waktu yang melingkupi karya itu diciptakan, tingkat perekonomian, tingkat pendidikan dan lain-lain.

\section{Puisi}

Puisi adalah karya sastra yang terkemas dalam beberapa baris yang memperlihatkan pertalian makna dan membentuk bait. Keindahan puisi terletak pada persamaan bunyi (rima), irama dan kandangan maknanya padat. Puisi memiliki keunikan tersendiri bila dibandingkan dengan karya sastra lainnya. Keunikan tersebut diantaranya puisi memiliki bentuk yang beraneka ragam. Ada yang baitnya atau barisnya sejajar semua dan adapula puisi yang memiliki baris tidak sejajar (Aminuddin, 2003:9).

Berdasarkan pembabakan waktu atau sistematika proses lahirnya puisi-puisi digolongkan dalam tiga katagori, yaitu :

1) Puisi lama

2) Puisi pengaruh arab 
3) Puisi baru

Puisi lama yaitu yang dilahirkan pada masa dahulu, masa kerajaan-kerajaan yang ada di indonesi. Puisi lama terdiri beberapa terdiri beberapa jenis, antara lain: bidal, pantun, syair, gurindam, seloka/pantun berkait, talibun, karmina/ pantun kilat dan mantar.

Bidal adalah kalimat-kalimat singkat yang mengandung suatu pengertian, sindiran, dan tangkisan bagi ahli sastra. Yang termasuk jenis bidal diantaranya: peribahasa, pepatah, kata arif/hadist melayu, dan pameo, pantun yaitu puisi yang terdiri atas 4 baris setiap baitnya, berirama silang ( $a b, a b)$, dua baris pertama baru sampiran, sedangkan dua baris berikutnya berupa isi.

Syair dalah puisi yang terdiri atas 4 baris setiap baitnya, berirama penuh (aaa), keempat barisnya berisi cerita atau lukisan tentang keadaan alam. Gurindam yaitu puisi yang terdiri atas dua baris setiap baitnya, berirama penuh (aa) dan berisi nasihat, petuah, wajengan atau nasihat.

Seloka/ pantun berkait yaitu puisi yang terdiri atas beberapa bait dan barisbaris pada bait yang satu diulang pada bait berikutnya. Talbun adaah puisi yang setiap baitnya terdiri atas 4 baris, setiap baris terdiri 4-5 suku kata, baris pertama dan kedua berupa sampiran sedangkan baris ketiga keempat berupa isi, dan berirama silang ( $a b, a b)$. Mantra adalah puisi yang dapat menimbulkan tenaga gaib yang biasa dipakai para pawang atau dukun. Mantra memiliki nilai magis yang biasa.

Puisi pengaruh arab yaitu puisi puisi yang ada di Indonesia namun mendapat pengaruh dari negeri Arab. Penduduk Indonesia yang mayoritas beragama islam memudahkan proses mempengaruhi puisi indonesia dengan kebudayaan atau nilai relagius yang ada pada negeri Arab.

Jenis puisi yang telah mendapat pengaruh dari negeri Arab diantaranya madan/ masnawi, rubai, nazam dan gazal. Madal adalah puisi yang baris puji-pujian terhadap tokoh masyarakat. Berirama penuh (aa, bb), setiap baris terdiri 10-14 suku kata. Rubai adalah puisi romantis yang setiap baitnya terdiri dari atas 8 baris dan setiap baris berakhir dengan kata yang sama.

Puisi baru adalah puisi yang tercipta atau diciptakan berdasarkan aturan yang tidak tetap dan mengalami proses adapatasi dari zaman ke zaman. Puisi baru banyak bentuknya seperti: distikon yang setiap baitnya terdiri atas dua baris, tersina yaitu puisi yang terdiri tiga baris setiap baitnya, kuatrin adalah puisi yang setiap baitnya terdiri atas empat baris, kuin yaitu puisi yang memiliki lima baris setiap barisnya, sextet adalah puisi yang setiap baitnya terdiri atas enam baris, septim yaitu puisi tujuh baris setiap baitnya, oktaf adalah puisi yang memiliki delapan baris setiap baitnya, soneta adalah puisi yang terdiri atas empat belas baris yang terbagi: dua kuantrin dan dua tersina. Berirama peluk (abba, abba, cdc, cdc). Puisi bebas adalah yang tidak terikat oleh jumlah baris dan rima. Puisi kontemporer adalah jenis puisi yang menyimpang dari aturan menulis puisi.

\section{METODE PENELITIAN}

$\begin{array}{lrr} & \text { PTK sebagai suatu bentuk penelitian } \\ \text { yang bersifat refleksi dengan } \\ \text { menggunakan tindakan-tindakan tertentu } \\ \text { agar dapat memperbaiki dan atau } \\ \text { meningkatkan }\end{array}$ pembelajaran di kelas secara professional. Berdasarkan beberapa pendapat para ahli PTK dapat disimpulkan bahwa bentuk kajian yang sistematika, kajian dilakukan oleh pelaku tindakan yaitu guru dan dilakukan untuk menperbaiki kondisi pembelajaran.

Tujuan dari PTK adalah memperbaiki dan meningkatkan kondisi belajar serta kualitas pembelajaran, meningkatkan layanan professional dalam konteks pembelajaran khususnya layanan kepada peserta didik sehingga tercipta layanan prima, memberikan kesempatan kepada guru untuk berimprovisasi dalam 
melakukan tindakan pembelajaran yang direncanakan secara tepat waktu dan sasarannya (Mulyasa, 2011 :89).

Manfaat dari PTK adalah untuk mengembangkan dan melakukan inovasi dalam pembelajaran, merupakan upaya pengembangan kurikulum di tingkat kelas dan untuk meningkatkan profesionalisme guru melalui upaya penelitian yang dilakukan.

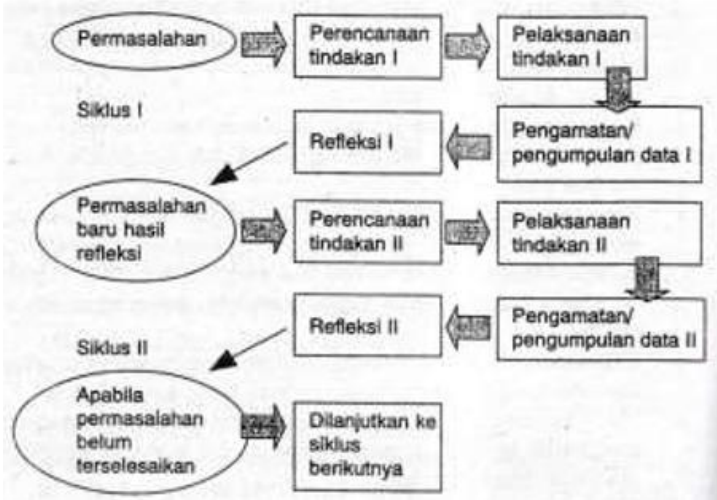

Gambar 2.1 Desain PTK Siklus dan Siklus 2 Sumber: Suharsimi, dkk, 2012 : 74

Metode yang dilakukan pada penelitian ini adalah metode penelitian tindakan kelas (PTK). PTK diterapkan sejalan dengan rencana rutin guru. Teknik pengumpulan data melalui siklus yang dilakukan dengan tahapan perencanaan, tindakan pengamatan dan refleksi.

Data penelitian diperoleh melalui tes membuat puisi dengan memanfaatkan lingkungan sekolah. Siswa diminta membuat puisi masing-masing satu buah selama dua tahap. Tahap pertama dilakukan di dalam kelas. Tahap kedua dan ketiga dilakukan di luar kelas. Selanjutnya setiap puisi yang dibuat atau diciptakan siswa diberi skor dengan menganalisis unsur-unsur batin dan unsur-unsur fisik yang digunakan siswa dalam puisinya.

Unsur - unsur batin puisi yang meliputi (1) tema, (2) perasaan, (3) nada dan (4) amanat. Sedangkan unsur - unsur fisik puisi yang dinilai meliputi (1) diksi, (2) imaji, (3) kata kongkret, (4) majas, (5) verifikasi dan (6) tatawajah.

Sumber data penelitian ini adalah siswa MTsN Model Banda Aceh I. Siswa yang menjadi sumber data adalah kelas I
MtsN Model Banda Aceh Tahun Pelajaran 2005/ 2006. Siswa kelas I MTsN Model Banda Aceh I berjumlah 460 siswa yang tersebar pada 10 kelas paralel yaitu kelas $I_{1}, I_{2}, I_{3}, \ldots$. dan $I_{10}$, sesuai dengan sifat penelitian ini yaitu tidak dimaksudkan untuk membuat seruas genelisasi, sumber data penelitian ditetapkan satu kelas saja, yaitu kelas $\mathrm{I}_{6}$. Penentuan kelas $\mathrm{I}_{6}$ sebagai sumber data didasarkan atas pertimbangan kelas $\mathrm{I}_{6}$ merupakan kelas yang kemampuan siswa yang memiliki NEM dan hasil ujian tes termasuk rendah. Proses belajar mengajar pada kelas $\mathrm{I}_{6}$ diperkirakan memiliki tingkat pembelajaran yang sulit dibandingkan dengan kelas yang lain. Siswa kelas $\mathrm{I}_{6}$ berjumlah 46 siswa. Dengan demikian, siswa kelas $\mathrm{I}_{6}$ berjumlah 46 merupakan sumber data penelitian ini.

Data diolah berdasarkan kelompok yang telah ditetapkan. Langkah-langkah yang ditempuh untuk mengelola data dalam penelitian ini sebagai berikut

1) Menyusun nilai dari urutan tertinggi ke urutan terendah

2) Menentukan range ( $\mathrm{Rg})$. Range adalah selisih antaa nilai tertinggi dan terendah ditambah 1 dengan $\mathrm{Rg}-\mathrm{H}+1$.

3) Menentukan jumlah kelas interval (K)

4) Menentukan lebar kelas interval (I)

5) Menyusun tabel distribusi frekuensi

6) Mencari nilai rata - rata ( Mean ). Denagn rumus:

$$
\mathrm{M}=\frac{\sum \mathrm{FX}}{\mathrm{N}}
$$

7) Memasukkan nilai rata - rata ke dalam katagori nilai kualitatif.

\section{HASIL DAN PEMBAHASAN}

\section{Hasil Tes Awal (Tahap Pertama)}

Pengamatan yang dilakukan dalam pelaksanaan penelitian ini menunjukkan bahwa beberapa strategi pembelajaran puisi yang tidak berkompotensi atau tidak terintegrasi dengan semua strategi 
pembelajaran pada penyampaian materi, sedangkan proses penciptaan puisi dan apresiasinya jarang dilakukan, malahan dikatagorikan tidak dilakukan.

Berdasarkan tes awal membuat puisi yang dilakukan, yakni membuat puisi dengan memedomani struktur pembangunan puisi diantaranya struktur batin dan struktur fisik. Struktur fisik terdiri atas diksi, pengimajian, kata konkret, majas, verifikasi dan tata wajah. Sedangkan struktur batin terdiri atas tema, perasaan, suasana dan amanat.

Berdasarkan tes awal yang dilakukan, yakni dengan memedomani 10 katagori, nilai maksimal 10 untuk diksi, pengimajian, kata konkret, majas, versifikasi, tatawajah, tema, perasaan, suasana dan amanat terlihat bahwa kemampuan siswa memanfaatkan lingkungan sekolah dalam menulis puisi masih kurang. Berdasarkan data hasil dari segi struktur fisik puisi adalah 41,65, struktur batin puisi adalah 27,60. Perolehan nilai rata-rata (Mean) yaitu 69,23 .

\section{Pelaksanaan Siklus I}

Tes yang dilakukan pada siklus I mengambil lokasi di luar kelas, tetapi masing dalam lingkungan sekolah. Siswa ditugaskan untuk dapat menulis puisi dengan memanfaatkan lingkungan sekolah. Unsur-unsur yang membangun puisi masih menjadi acuan dalam penelitian baik itu unsur fisik maupun unsur batin. Hasil dari segi struktur fisik puisi terjadi peningkatan dari 41,65 menjadi 43,90, struktur batin puisi dari 27,60 menjadi 28,33. Rata-rata (Mean) perolehan nilainya yaitu dari 69,23 menjadi 72,17 .

Hasil yang diperoleh menunjukkan peningkatan nilai siswa dalam memanfaatkan lingkungan sekolah pada penulisan puisi, kondisi ini mengindikasikan bahwa siswa benar-benar memanfaatkan tes pertama sebagai acuan pertama dalam membuat puisi.

\section{Pelaksanaan Siklus II}

Tes yang dilakukan pada siklus I mengambil lokasi di luar kelas, tetapi masih dalam lingkungan sekolah dan berbeda tempat dari siklus pertama. Siswa ditugaskan untuk dapat menulis puisi dengan mamanfaatkan lingkungan sekolah. Struktur yang membangun puisi masih menjadi acuan dalam penilaian baik itu struktur fisik maupun struktur batin. Struktur fisik terdiri atas diksi, pengimajian, kata kongkret, majas, versifikasi, dan tatawajah, sedangkan struktur batin terdiri atas tema, perasaaan, suasana dan amanat.

Berdasarkan hasil perolehan nilai pada siklus I selanjutnya diberikan tindaka pada siklus 2. Tindakan yang diberikan pada siklus kedua meliputi proses pembuatan puisi yang didasari pada struktur fisik dan struktur batin. Struktur fisik terdiri atas diksi, imaji, kata kongkret, majas, verifikasi dan tatawajah. Struktur batin terdiri atas tema, perasaan, nada dan amanat.

Hasil siklus 1 dipadukan dengan hasil tes siklus 2 menunjukkan adanya peningkatan yang signifikan atau nyata. Hal ini dapat diamati bahwa rata-rata kemampuan menciptakan puisi dengan memanfaatkan lingkungan sekolah dari struktur fisik meningkat dari 43,9 menjadi 44,15 , rata-rata memahami dan mengekspresikan struktur batin meningat 28,33 menjadi 29,35 .

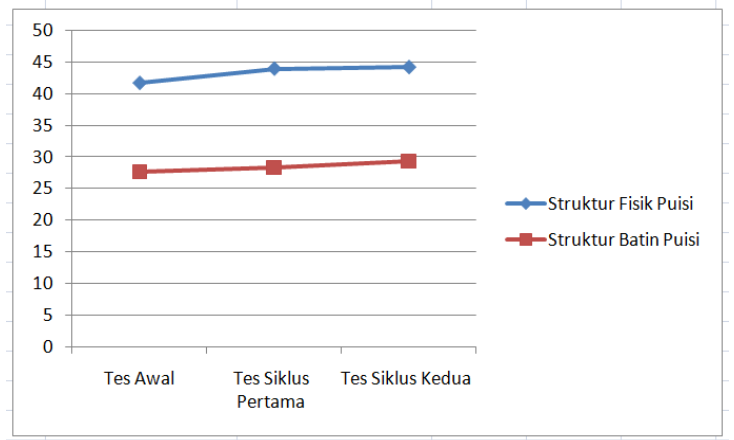

Gambar 4.1 Grafik ragam penilaian

Sedangkan rata-rata (mean) perolehan nilai kemampuan siswa dalam memanfaatkan lingkungan dalam menulis puisi berdasarkan struktur fisik puisi dan 
struktur batin puisi menunjukkan peningkatan dari 72,17 menjadi 73,50.

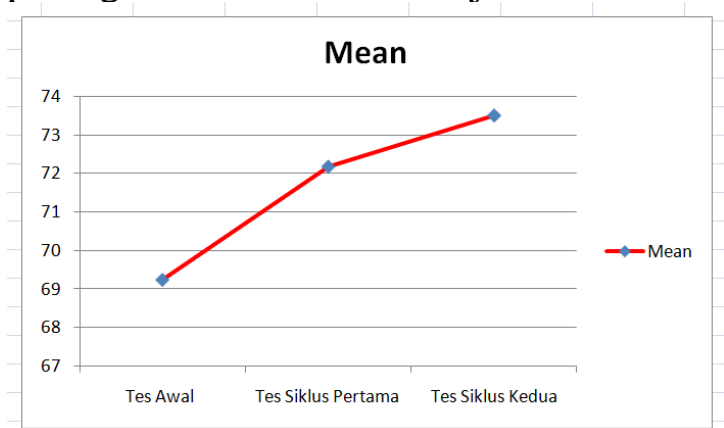

Gambar 4.2 Grafik nilai rata-rata (mean) dari ragam penilaian

\section{SIMPULAN}

1. Berdasarkan hasil penulisan puisi siswa didapati hasil: struktur fisik tes awal 41,65, tes siklus pertama 43,9, siklus kedua 44,15 dan struktur batin tes awal 27,60 , tes siklus pertama 28,33 dan tes siklus kedua 29,35. Nilai rata-rata (Mean) kemampuan siswa memanfaatkan lingkungan dalam menulis puisi menunjukkan peningkatan dari tes awal sebesar 69,23, tes siklus pertama 72,17 dan tes siklus kedua menjadi 73,50.

2. Berdasarkan hasil analisis data, maka penelitian ini dapat disimpulkan bahwa dalam menulis puisi dengan memanfaatkan lingkungan sekolah yang dilakukan oleh siswa sangat berpengaruh terhadap peningkatan nilai puisi yang dibuat siswa. Peningkatan tersebut terindifikasi melalui penelitian tindakan kelas.

\section{DAFTAR PUSTAKA}

Aminuddin. 2003. Apresiasi Puisi. Direktorat Pendidikan Lanjutan pertama. Direktorat Jenderal Pendidikan Dasar dan Menengah. Daparteman Pendidikan Nasional.

Ardiana, Leo Idra. 2001a. "Pembelajaran Kontekstual."Makalah Disajikan dalam Pelatihan Calon Pelatih Guru SLTP, Diselenggarakan oleh Dikmenum, 18 Okteber sampai. Okteber 2001 di Surabaya.

Arikunto Suharsimi, dkk. 2012. Penelitian Tindakan Kelas. Jakarta: Bumi Aksara

Endraswara, Suwardi. 2003. Membaca, Menulis, Mengajarkan Sastra. Sastra berbasis Kompetensi. Yogyakarta: Kota Kembang.

Mulyasa, 2011. Praktik Penelitian Tindakan Kelas. Bandung: PT. Remaja Rosdakarya.

Nasution, S. 1986. Didaktik Asas-Asas Mengajar. Bandung: Jemmars.

Nida Rahmawati. 2017. dengan judul peningkatan kemampuan menulis puisi bebas melalui penggunaan metode estafet writing (Penelitian Tindakan Kelas pada Siswa Kelas VIII F SMP Negeri 1 Baregbeg). Jurnal ilmiah Diksatrasia, Vol. 1 No.2

Rahmanto, B. 1996. Metode pengajaran sastra. Yogyakarta: Kanisius

Semi, Atar. 1993. Metode Penelitian Satra. Bandung: Angkasa.

Setiawan, dkk. 2003. Penulisan Kreatif. Jakrta: Direktorat Pendidikan Lanjutan Pertama.

Direktorat Jenderal Pendidikan Dasar dan Menengah. Dapatermen Pendidikan Nasional.

Soermadjo, Jakob. 2001. Catatan Kecil Menulis Cerpen. Yogyakarta: Pustaka Pelajar Sujino. 1983. Pengantar Statistik Pendidikan. Jakarta: Rineka Cipta

Teuw, A. 1980. Satra Baru Indonesia. Yogyakarta: Nusa Indah.

Tim Pelatihan Proyek PGSM. 1999. Penelitian Tindakan Kelas. Jakarta: Dapatermen Pendidikan dan Kebudayaan Republik Indonesia.

Trimansyah, Bambang. 1999. Petunjuk Guru Belajar Bahasa Indonesia Untuk SLTP. Jakarta: PT Mapan. 